\title{
Phenol biodegradation and its effect on the nitrification process
}

\author{
L. Amor, M. Eiroa, C. Kennes, M.C. Veiga \\ Water Research, Volume 39, Issue 13, August 2005, Pages 2915-2920 \\ DOI: 10.1016/j.watres.2005.05.019
}

\begin{abstract}
Phenol biodegradation under aerobic conditions and its effect on the nitrification process were studied, first in batch assays and then in an activated sludge reactor. In batch assays, phenol was completely biodegraded at concentrations ranging from 100 to $2500 \mathrm{mg} \mathrm{l}^{-1}$. Phenol was inhibitory to the nitrification process, showing more inhibition at higher initial phenol concentrations. At initial phenol concentrations above $1000 \mathrm{mg} \mathrm{l}^{-1}$, the level of nitrification decreased. In the activated sludge reactor, the applied ammonium loading rate was maintained at $140 \mathrm{mg} \mathrm{N}-\mathrm{NH}_{4}{ }^{+} \mathrm{l}^{-1} \mathrm{~d}^{-1}(350 \mathrm{mg} \mathrm{N}-$ $\mathrm{NH}_{4}^{+} \mathrm{l}^{-1}$ ) during the operation time. However, the applied organic loading rate was increased stepwise from 30 to $2700 \mathrm{mg} \mathrm{COD} \mathrm{l}^{-1} \mathrm{~d}^{-1}$ by increasing the phenol concentration from 35 up to $2800 \mathrm{mg} \mathrm{l}^{-1}$. High phenol removal efficiencies, above 99.9\%, were maintained at all the applied organic loading rates. Ammonium removal was also very high during the operation period, around $99.8 \%$, indicating that there was no inhibition of nitrification by phenol.
\end{abstract}

\section{Keywords}

Phenol; Ammonium; Aerobic biodegradation; Nitrification; Toxicity

\section{Introduction}

Phenol is a toxic compound present in wastewaters from many different industries, such as petrochemical industries, chemical industries and resin producing industries. In some cases nitrogen may be present as well. Therefore, the biological treatment of these wastewaters requires the simultaneous removal of phenol and nitrogen, which can be done in an activated sludge reactor in two successive steps. During the nitrification step, ammonium is oxidized to nitrate under aerobic conditions; and during the denitrification step, nitrate is reduced to molecular nitrogen in the presence of a carbon source under anoxic conditions. Nitrification is commonly the rate-limiting step of the overall nitrogen removal. In the presence of toxic compounds as phenol, even at low concentrations, the nitrification process may be inhibited.

Phenol removal has been the subject of numerous investigations. There are several references about phenol biodegradation in both anoxic (Fang and Zhou, 1997; Blaszczyk et al., 1998; Sarfaraz et al., 2004) and aerobic conditions (Buitrón et al., 1998; González et al., 2001; Yamagishi et al., 2001). Buitrón et al. (1998) studied the degradation of phenol by acclimated activated sludge and by isolated bacteria. Activated sludge was acclimated for 70 days to phenol and chlorophenols and then the microorganisms responsible for degradation were isolated. The acclimated sludge degradation rates were higher than those of pure strains. The specific phenol uptake rate 
for acclimated activated sludge was $407 \mathrm{mg} \mathrm{g}^{-1} \mathrm{VSS} \mathrm{d}^{-1}$ while it was $54 \mathrm{mg} \mathrm{g}^{-1} \mathrm{VSS} \mathrm{d}^{-1}$ for the more active pure strain. González et al. (2001) worked with two different aerobic systems: a stirred tank and a fluidized bed reactor, in order to evaluate phenol biodegradation by a pure culture of Pseudomonas putida. Both bioreactors showed high phenol degradation efficiencies, higher than $90 \%$, for phenol loading rates up to $4000 \mathrm{mg} \mathrm{l}^{-1} \mathrm{~d}^{-1}$. Yamagishi et al. (2001) studied the simultaneous removal of phenol and ammonium by activated sludge biomass which had been acclimated with phenol for over 15 years. Phenol was completely removed, and ammonium was simultaneously nitrified to nitrate. The nitrification rate reached $200 \mathrm{mg} \mathrm{N}-\mathrm{NH}_{4}^{+} \mathrm{l}^{-1} \mathrm{~d}^{-1}$ when phenol was removed at a rate up to $714 \mathrm{mg}$ COD $\mathrm{l}^{-1} \mathrm{~d}^{-1}$.

In wastewaters from resin producing factories the organic matter is present mainly as formaldehyde but odd effluents with high concentrations of phenol are also generated when the manufacturing process is changed. Thus, it is necessary to study the treatment of these wastewaters with high levels of phenol and ammonium. The effect of phenol on nitrogen removal at high phenol loading rates and using unacclimated biomass has not been investigated deeply. The goal of this work was to analyze phenol biodegradation under aerobic conditions and its effect on the nitrification process. Therefore, aerobic assays were undertaken first in batch and then in an activated sludge reactor.

\section{Materials and methods}

\subsection{Aerobic batch assays}

Duplicate experiments were undertaken under aerobic conditions in $500 \mathrm{ml}$ screwcapped vials containing $100 \mathrm{ml}$ aqueous medium. The vials were inoculated with $3.5 \mathrm{~g}$

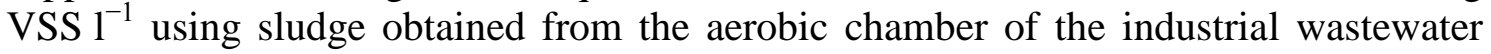
treatment plant of a resin producing factory. The medium was supplemented with $10 \mathrm{ml}$ nutrients solution and $0.05 \mathrm{ml}$ trace elements solution. The composition of these solutions was mentioned elsewhere (Eiroa et al., 2004). The initial pH was adjusted to 7.9 using $\mathrm{NaHCO}_{3}$ buffer.

Finally, phenol (100-2500 $\mathrm{mg} \mathrm{l}^{-1}$ ) and $250 \mathrm{mg} \mathrm{N}-\mathrm{NH}_{4}{ }^{+} \mathrm{l}^{-1}$ were added in order to study phenol biodegradation and the nitrification process. Phenol, nitrite, nitrate and ammonium concentrations were measured at regular time intervals. Assays were performed in a thermostatic chamber at $20^{\circ} \mathrm{C}$ and with constant shaking at $200 \mathrm{rpm}$.

\subsection{Activated sludge reactor}

A lab-scale activated sludge reactor consisting of an aeration basin coupled to an external settler with a useful volume of $1.8 \mathrm{l}$ was used. The scheme of the continuous experimental unit was shown elsewhere (Eiroa et al., 2005a). In this unit, water to be treated was aerated and mixed with the sludge in the aeration basin. The treated water was separated from the sludge in the settler and the sludge was recycled in a temporized fashion to the aeration basin. Diffusers, located at the bottom of the aeration basin, supplied air of an air pump and maintained complete mixing. The reactor was initially inoculated with sludge obtained from the aerobic chamber of the full-scale wastewater treatment plant of a resin producing industry. 
A synthetic wastewater containing nutrients (350 mg N-NH${ }_{4}^{+} \mathrm{l}^{-1}$ ), trace elements $\left(0.05 \mathrm{ml} \mathrm{l}^{-1}\right), \mathrm{NaHCO}_{3}\left(4800 \mathrm{mg} \mathrm{l}^{-1}\right)$ and phenol was continually fed to the unit by a peristaltic pump. The unit was operated at a hydraulic retention time of 2.5 days. The applied ammonium loading rate was maintained constant during all the operation time (140 mg N- $\mathrm{NH}_{4}^{+} \mathrm{l}^{-1} \mathrm{~d}^{-1}$ ). However, the applied organic loading rate was increased stepwise (30-2700 mg COD l${ }^{-1} \mathrm{~d}^{-1}$ ) by increasing the phenol concentration (35$2800 \mathrm{mg} \mathrm{l}^{-1}$ ). Each organic loading rate was maintained in the system until reaching steady-state conditions. Phenol, nitrite, nitrate, ammonium, COD, VSS, dissolved oxygen and $\mathrm{pH}$ were measured on a regular basis.

\subsection{Analytical methods}

All samples were filtered through a $0.45 \mu \mathrm{m}$ nylon membrane before analysis. Phenol was determined using a Hewlett-Packard 1100 liquid chromatograph equipped with a C18 ODS column ( $25 \mathrm{~cm} \times 4 \mathrm{~mm}$ ID) and a UV diode-array detector. The mobile phase was methanol:water (60:40) and detection was performed at $280 \mathrm{~nm}$. Nitrite and nitrate were analyzed by capillary electrophoresis using a Hewlett-Packard ${ }^{3 \mathrm{D}} \mathrm{CE}$ system with a microcapillary tube of fused silica ( $40 \mathrm{~cm} \times 50 \mu \mathrm{m}$ ID). Sodium phosphate solution was employed as the electrolyte. UV detection was undertaken at a wavelength of $214 \mathrm{~nm}$ and $450 \mathrm{~nm}$ as reference. Ammonium, dissolved oxygen, COD, VSS and $\mathrm{pH}$ were evaluated according to Standard Methods ( APHA, 1998). Ammonium and dissolved oxygen were determined using selective electrodes. COD was analyzed by the closed reflux colorimetric method while VSS were analyzed by the gravimetric method.

\section{Results and discussion}

\subsection{Aerobic batch assays}

\subsubsection{Nitrification in the presence of phenol}

In the batch assays the $\mathrm{pH}$ was between 7.3 and 7.9, which is close to the optimum range for nitrifying bacteria (Antoniou et al., 1990). The dissolved oxygen concentration at the end of the assays was always higher than $4 \mathrm{mg} \mathrm{l}^{-1}$. Phenol biodegradation was studied at concentrations ranging from 100 to $2500 \mathrm{mg} \mathrm{l}^{-1}$. The evolution of phenol concentration in the assays is shown in Fig. 1. Phenol was completely removed at all concentrations. Its biodegradation started after an acclimation period of the sludge. This lag phase was longer at higher initial phenol concentrations. Initial phenol consumption rates from 16 to $251 \mathrm{mg} \mathrm{g}^{-1} \mathrm{VSS} \mathrm{d}^{-1}$ (38-597 $\mathrm{mg} \mathrm{COD} \mathrm{g}^{-1}$ $\mathrm{VSS} \mathrm{d}^{-1}$ ) were obtained for substrate concentrations ranging from 100 to $2500 \mathrm{mg} \mathrm{l}^{-1}$. 


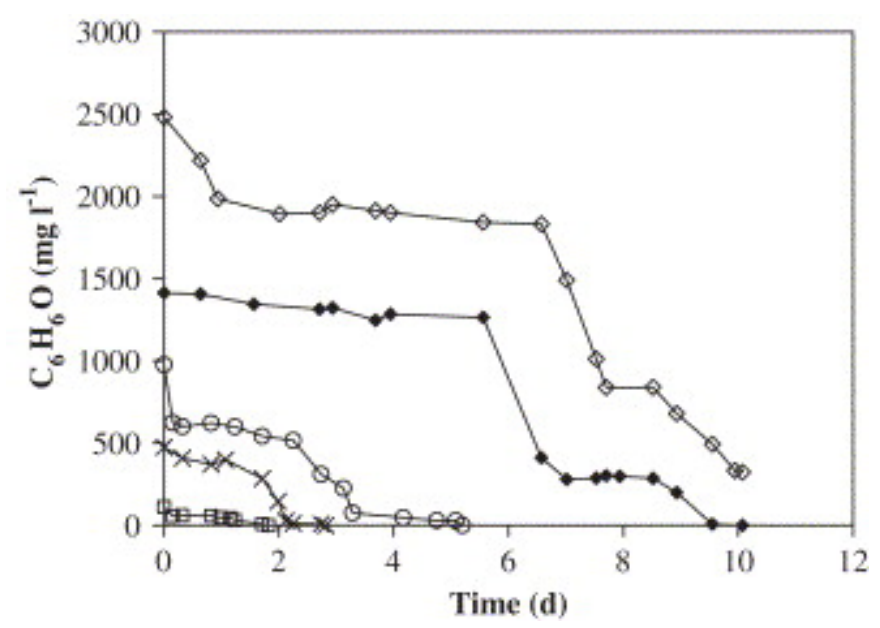

Fig. 1.

Phenol biodegradation at different concentrations: ( $\square)$ 100, (×) 500, (०) 1000, (•) 1400 and $(\diamond) 2500 \mathrm{mg} \mathrm{C}_{6} \mathrm{H}_{6} \mathrm{Ol}^{-1}$.

Goudar et al. (2000) also studied phenol biodegradation in batch assays using a mixed culture adapted to phenol. Initial phenol concentrations from 100 to $1300 \mathrm{mg} \mathrm{l}^{-1}$ were tested. Phenol inhibited biodegradation at high concentrations. For phenol concentrations above $1300 \mathrm{mg} \mathrm{l}^{-1}$, no phenol degradation was observed. Despite using an acclimated microbial culture as inoculum, a lag phase was also observed in all experiments.

Nitrification was investigated both without phenol and in the presence of different phenol concentrations. The evolution of nitrite and nitrate concentrations is shown in Fig. 2. In the assays without phenol, the nitrification process started immediately after inoculation and without accumulation of nitrite. While in the assays with phenol, the nitrification process started after phenol was completely degraded. Therefore, phenol caused an inhibitory effect on the nitrification process. Nitrification was possible with limited inhibition at low initial phenol concentrations, observing increased inhibitory effects at higher concentrations. Nitrite production was observed, increasing its accumulation at higher initial phenol concentrations. At initial phenol concentrations above $1000 \mathrm{mg} \mathrm{l}^{-1}$, the level of nitrification decreased. At initial phenol concentrations of 1400 and $2500 \mathrm{mg} \mathrm{l}^{-1}$, the amount of nitrite increased and the amount of nitrate was very low, showing that nitrification was inhibited by phenol. Thus, the increase in initial phenol concentration caused a decrease in the nitrification percentage with accumulation of nitrite and ammonium. 

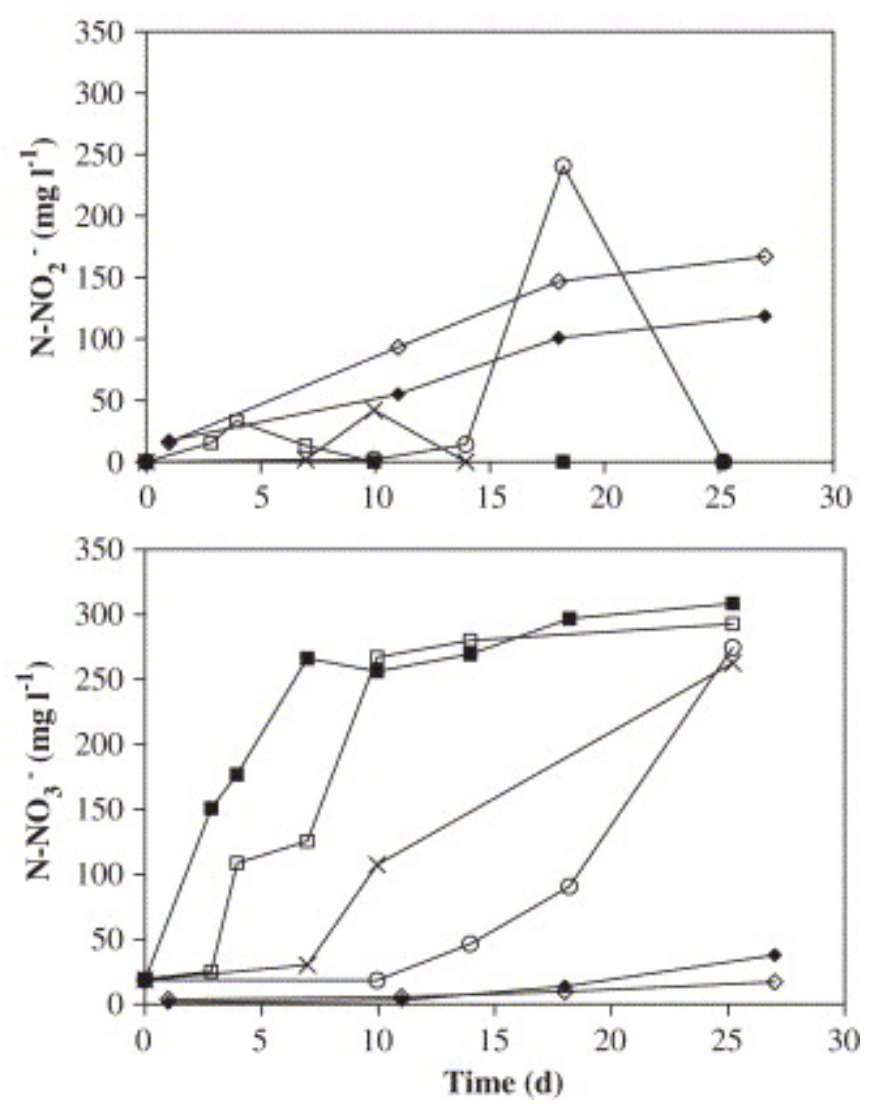

Fig. 2.

Nitrification without phenol and in the presence of different phenol

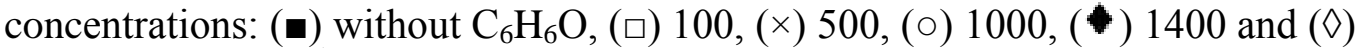
$2500 \mathrm{mg} \mathrm{C}_{6} \mathrm{H}_{6} \mathrm{O} \mathrm{l}^{-1}$.

In batch assays that were carried out with sludge obtained from the same industrial wastewater treatment plant (Eiroa et al., 2004), nitrification in the presence of different formaldehyde concentrations (30-3890 $\mathrm{mg} \mathrm{l}^{-1}$ ) was investigated. In these assays, the addition of formaldehyde was also inhibitory for the nitrification process, showing higher inhibition levels when increasing the initial formaldehyde concentration. Gómez et al. (2000) studied the effect of different concentrations of several volatile organic compounds on the nitrification process in batch cultures. They also found that an increase in the concentration of volatile organic compound provoked an increase in the inhibition of the nitrification process.

\subsection{Activated sludge reactor}

Phenol biodegradation and its effect on nitrification were also studied in an activated sludge unit. The $\mathrm{pH}$ level in the reactor fluctuated between 7.2 and 8.1. Dissolved oxygen was maintained between 3.9 and $8.2 \mathrm{mg} \mathrm{l}^{-1}$ by aeration and temperature was around $20^{\circ} \mathrm{C}$. The biomass concentration in the unit increased from 3.5 up to $12.0 \mathrm{~g}$ VSS $^{-1}$ after five months of operation. No biomass was purged from the reactor during the experimental period. With regard to the biomass concentration in the effluent, it was lower than $50 \mathrm{mg} \mathrm{VSS}^{-1}$ during the operation period. Sludge with good settling properties was obtained since high dissolved oxygen concentrations were maintained in 
the unit. It is known that high values of dissolved oxygen produce flocs with high density and good settling properties (Wilén and Balmér, 1999).

Before this research, the activated sludge unit had been operating for several months at an ammonium loading rate of $140 \mathrm{mg} \mathrm{N}-\mathrm{NH}_{4}{ }^{+} \mathrm{l}^{-1} \mathrm{~d}^{-1}$, obtaining ammonium removals around $99.9 \%$. During this study, the applied ammonium loading rate was maintained constant while the organic loading rate was increased. The unit was operated at a hydraulic retention time of 2.5 days.

\subsubsection{Phenol biodegradation}

The organic loading rate applied to the activated sludge unit was changed stepwise in order to study phenol biodegradation. The applied organic loading rate was increased from 30 up to $2700 \mathrm{mg} \mathrm{COD} \mathrm{l}^{-1} \mathrm{~d}^{-1}$ by increasing the phenol concentration from 35 to $2800 \mathrm{mg} \mathrm{l}^{-1}$. The evolution of phenol in the influent and effluent of the unit is shown in Fig. 3A. While the phenol concentration in the influent was increased, the phenol concentration in the effluent remained always under the detection limit (lower than $0.1 \mathrm{mg} \mathrm{l}^{-1}$ ). The phenol concentration in the effluent was always lower than the maximum discharge value of $1 \mathrm{mg} \mathrm{l}^{-1}$ permitted by the Spanish legislation. High phenol removal efficiencies, above $99.9 \%$, could be maintained at all the applied organic loading rates. The unit was stable throughout the five-month operation period. The higher specific phenol removal rate obtained was $225 \mathrm{mg} \mathrm{COD} \mathrm{g}^{-1} \mathrm{VSS} \mathrm{d}^{-1}$.

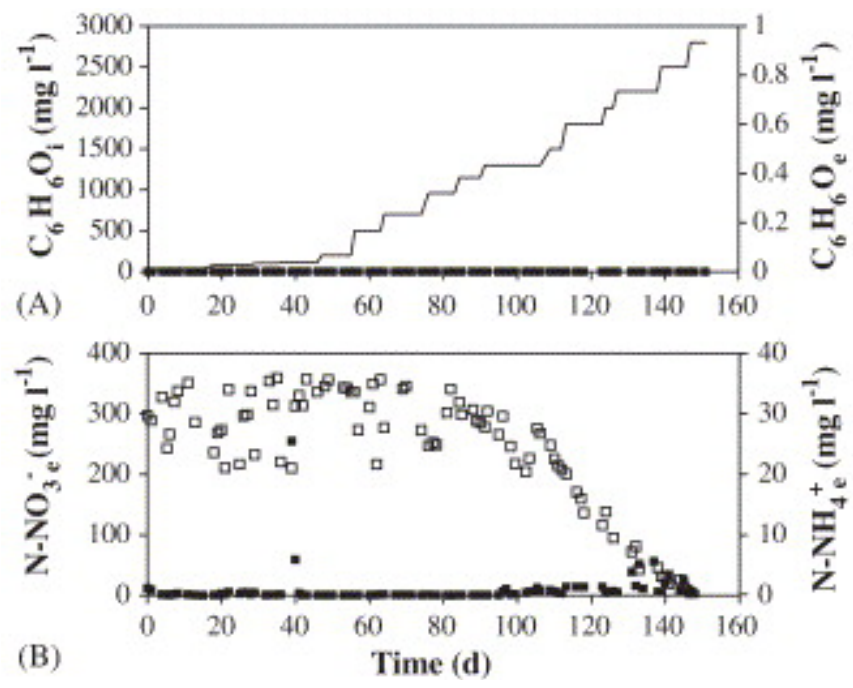

Fig. 3.

(A) Phenol concentration in the influent (-) and in the effluent (a). (B) Evolution of the nitrogen compounds concentration in the effluent: ammonium (घ) and nitrate ( $\square$ ).

González et al. (2001) studied aerobic phenol biodegradation in a stirred tank reactor by a pure culture of Pseudomonas putida. The phenol concentration in the influent was maintained at $1000 \mathrm{mgl}^{-1}$ while the hydraulic retention time was progressively decreased from 4 to 0.25 days. For phenol loading rates between 600 and $1200 \mathrm{mg}$ $\operatorname{COD~l}^{-1} \mathrm{~d}^{-1}$, the system was stable and phenol concentration in the effluent was under $5 \mathrm{mg} \mathrm{l}^{-1}$. However, for phenol loading rates higher than $2400 \mathrm{mg} \mathrm{COD} \mathrm{l}^{-1} \mathrm{~d}^{-1}$, the system needed longer time to remove the phenol. When the loading rate was fixed to the 
new value, the phenol concentration in the effluent increased, went through a maximum to further decrease to stable values. Moreover these stable values were always higher than the maximum discharge value permitted by the Spanish legislation $\left(1 \mathrm{mg} \mathrm{l}^{-1}\right)$, unlike our assays.

Eiroa et al. (2005b) also investigated phenol biodegradation but under anoxic conditions using an upflow sludge blanket reactor. In such case, the applied organic loading rate was increased from 30 to $1300 \mathrm{mg} \mathrm{COD} \mathrm{l}{ }^{-1} \mathrm{~d}^{-1}$. Phenol removal efficiencies above $90.6 \%$ were obtained at phenol concentrations in the influent between 27 and $755 \mathrm{mg} \mathrm{l}^{-1}$. However, when the phenol concentration was increased to $1010 \mathrm{mg} \mathrm{l}^{-1}$, its removal efficiency decreased. The higher specific removal rate obtained in this case was $99 \mathrm{mg} \mathrm{COD} \mathrm{g}^{-1} \mathrm{VSS} \mathrm{d}^{-1}$. Therefore, higher specific removal rates were achieved under aerobic conditions than under anoxic conditions.

The COD in the influent and effluent of the unit is shown in Fig. 4. While phenol was easily degraded in the activated sludge reactor, a remaining COD was present in the effluent of the unit. The COD in the effluent varied between 53 and $223 \mathrm{mg} \mathrm{l}^{-1}$, with a mean value of $122 \mathrm{mg} \mathrm{l}^{-1}$. The remaining COD in the effluent might be due to inert bio products released from the sludge.

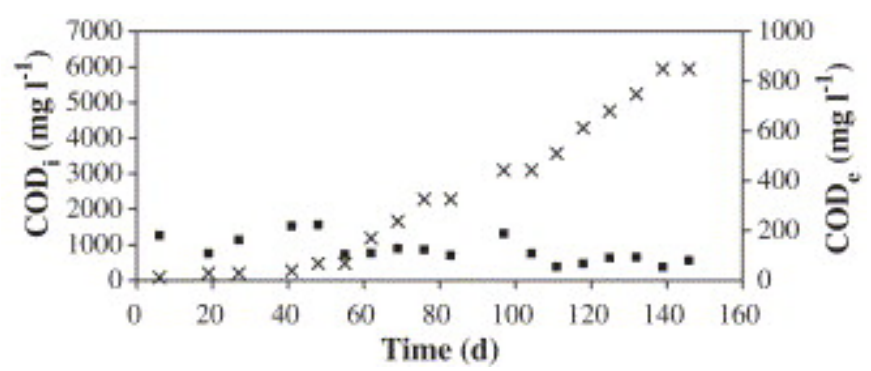

Fig. 4.

Chemical oxygen demand (COD) in the influent $(\times)$ and in the effluent $(\boldsymbol{\square})$.

\subsubsection{Nitrification in the presence of phenol}

The ammonium concentration in the influent was maintained constant at $350 \mathrm{mg} \mathrm{l}^{-1}$, being the applied ammonium loading rate $140 \mathrm{mg} \mathrm{N}-\mathrm{NH}_{4}{ }^{+} \mathrm{l}^{-1} \mathrm{~d}^{-1}$; while the organic loading rate was increased. The evolution of the ammonium and nitrate concentrations in the effluent of the unit is shown in Fig. 3B. The nitrite concentration in the effluent was omitted because this compound was not detected at any time. The ammonium concentration in the effluent was between 0.02 and $5.6 \mathrm{mg} \mathrm{N}-\mathrm{NH}_{4}{ }^{+} \mathrm{l}^{-1}$ at all applied phenol loading rates, except on days 39-40 when a problem with the aeration occurred. Therefore, ammonium removal was very high during the operation period, around $99.8 \%$, indicating that there was no inhibition of nitrification by phenol.

Yamagishi et al. (2001) also studied the simultaneous removal of phenol and ammonium in an activated sludge process. Biomass, which had been acclimated with phenol for over 15 years, was used as inoculum. Phenol was completely removed, and ammonium was simultaneously nitrified to nitrate. The nitrification rate reached $200 \mathrm{mg}$ $\mathrm{N}-\mathrm{NH}_{4}{ }^{+} \mathrm{l}^{-1} \mathrm{~d}^{-1}\left(25 \mathrm{mg} \mathrm{N}-\mathrm{NH}_{4}{ }^{+} \mathrm{g}^{-1} \mathrm{VSS} \mathrm{d}^{-1}\right)$ when phenol was removed at a rate of up to $714 \mathrm{mg} \mathrm{COD} \mathrm{l}^{-1} \mathrm{~d}^{-1}\left(89 \mathrm{mg} \mathrm{COD} \mathrm{g}^{-1} \mathrm{VSS} \mathrm{d}^{-1}\right)$. In our case, in spite of using 
unacclimated biomass, ammonium removal took place at significantly higher specific phenol loading rates (225 $\mathrm{mg} \mathrm{COD} \mathrm{g}^{-1} \mathrm{VSS} \mathrm{d}^{-1}$ ).

Up to a phenol concentration of $1500 \mathrm{mg} \mathrm{l}^{-1}$ (day 113 of operation), the nitrate concentration in the effluent varied between 200.4 and $358.8 \mathrm{mg} \mathrm{l}^{-1}$. During this period, nitrification percentages of around $82.4 \%$ were obtained. Afterwards, the nitrate concentration in the effluent decreased when the phenol concentration was increased. This decrease can be basically attributed to denitrification and to some ammonium assimilation by the heterotrophs. The same decrease was observed in a similar experiment performed in our laboratory in the same type of reactor but with formaldehyde instead of phenol (Eiroa et al., 2005a).

Denitrification in the aerobic unit could occur because of anaerobic micro zones in the centre of the sludge flocs. Organic matter served as the electron donor. The increase in the phenol concentration could enhance denitrification. In order to explain this decrease in the nitrate concentration by denitrification, the addition of phenol to the influent was stopped on day 151. As a result, the nitrate concentration in the effluent increased from this day. Hence, simultaneous nitrification and denitrification took place in the unit. Other authors also observed nitrogen loss due to denitrification (Yamagishi et al., 2001).

Another possible mechanism explaining decrease in nitrate concentration in the effluent can be ammonium assimilation by the heterotrophs. Ammonium assimilation by the nitrifiers is small because of their low growth rate. However, assimilation becomes significant when the heterotrophs grow with organic matter (Rostron et al., 2001). The biomass in the reactor increased substantially and the assimilation of ammonium by the heterotrophs was faster than nitrification. Only excess ammonium was utilized by the nitrifiers for nitrification (Hanaki et al., 1990; Cheng and Chen, 1994). Higher phenol loading rates resulted in more growth of heterotrophs and thus, in more ammonium assimilation by these heterotrophs. Therefore, ammonium assimilation by the heterotrophs reduced the amount of ammonium available to the nitrifiers, and decreased the achievable nitrification percentage.

In the aerobic batch assays, the addition of phenol was inhibitory for the nitrification process. In the activated sludge reactor, inhibition of ammonium removal by phenol was not observed even at high organic loading rates. This absence of inhibition can be due to the negligible phenol concentration in the unit as a result of fast mixing in the stirred tank reactor as well as its fast removal. Therefore, the continuous aerobic treatment of wastewaters with high levels of phenol and ammonium can efficiently be undertaken in an activated sludge reactor.

\section{Conclusions}

\subsection{Aerobic batch assays}

Phenol was completely biodegraded at concentrations ranging from 100 to $2500 \mathrm{mg} \mathrm{l}^{-1}$; however, it was inhibitory to the nitrification process. The increase in initial phenol concentration caused a decrease in the nitrification percentage with accumulation of nitrite and ammonium.

\subsection{Activated sludge reactor}


The ammonium loading rate was maintained at $140 \mathrm{mg} \mathrm{N}-\mathrm{NH}_{4}{ }^{+} \mathrm{l}^{-1} \mathrm{~d}^{-1}$ during all the operation time. However, the organic loading rate was increased stepwise from 30 to $2700 \mathrm{mg} \mathrm{COD} \mathrm{l}^{-1} \mathrm{~d}^{-1}$ by increasing the phenol concentration from 35 to $2800 \mathrm{mg} \mathrm{l}^{-1}$.

High phenol removal efficiencies, above 99.9\%, were maintained at all the applied organic loading rates. Ammonium removal was also very high, around 99.8\%, indicating that there was no inhibition of nitrification by phenol.

In wastewaters from resin producing factories, odd effluents with high concentrations of phenol are generated. The results indicate that the continuous aerobic treatment of wastewaters with high levels of phenol and ammonium can efficiently be undertaken. Therefore, these wastewaters could be treated in an activated sludge reactor in spite of using unacclimated biomass.

\section{Acknowledgments}

The present research was financed by the Xunta de Galicia (projects PGIDIT03PXIC10304PN and PGIDIT03TAM13E) and the Spanish Ministry of Science and Technology (project PPQ2002-02882).

\section{References}

P. Antoniou, J. Hamilton, B. Koopman, R. Jain, B. Holloway, G. Lyberatos, S.A. Svoronos

Effect of temperature and $\mathrm{pH}$ on the effective maximum specific growth rate of nitrifying bacteria

Water Res., 24 (1) (1990), pp. 97-101

APHA, 1998. Standard Methods for the Examination of Water and Wastewater, 20th ed., Washington, DC, USA.

M. Blaszczyk, M. Przytocka-Jusiak, A. Suszek, A. Mielcarek

Microbial degradation of phenol in denitrifying conditions

Acta Microbiol. Pol., 47 (1) (1998), pp. 65-75

G. Buitrón, A. González, L.M. López-Marín

Biodegradation of phenolic compounds by an acclimated activated sludge and isolated bacteria

Water Sci. Technol., 37 (4-5) (1998), pp. 371-378

S. Cheng, W. Chen

Organic carbon supplement influencing performance of biological nitritification in a fluidized bed reactor

Water Sci. Technol., 30 (11) (1994), pp. 131-142

M. Eiroa, C. Kennes, M.C. Veiga

Formaldehyde biodegradation and its inhibitory effect on nitrification

J. Chem. Technol. Biotechnol., 79 (2004), pp. 499-504 
M. Eiroa, C. Kennes, M.C. Veiga

Simultaneous nitrification and formaldehyde biodegradation in an activated sludge unit Bioresource Technol. (2005)

M. Eiroa, A. Vilar, L. Amor, C. Kennes, M.C. Veiga

Biodegradation and effect of formaldehyde and phenol on the denitrification process

Water Res., 39 (2005), pp. 449-455

H.H.P. Fang, G.M. Zhou

Denitrification of phenolic wastewater by immobilized sludge

Environ. Technol., 18 (1997), pp. 827-834

J. Gómez, R. Méndez, J.M. Lema

Kinetic study of addition of volatile organic compounds to a nitrifying sludge

Appl. Biochem. Biotechnol., 87 (2000), pp. 189-202

G. González, G. Herrera, M.T. García, M. Peña

Biodegradation of phenol in a continuous process: comparative study of stirred tank and fluidized-bed bioreactors

Bioresource Technol., 76 (2001), pp. 245-251

C.T. Goudar, S.H. Ganji, B.G. Pujar, K.A. Strevett

Substrate inhibition kinetics of phenol biodegradation

Water Environ. Res., 72 (1) (2000), pp. 50-55

K. Hanaki, C. Wantawin, S. Ohgaki

Effects of the activity of heterotrophs on nitrification in a suspended-growth reactor

Water Res., 24 (3) (1990), pp. 289-296

W.M. Rostron, D.C. Stuckey, A.A. Young

Nitrification of high strength ammonia wastewaters: comparative study of immobilisation media

Water Res., 35 (5) (2001), pp. 1169-1178

S. Sarfaraz, S. Thomas, U.K. Tewari, L. Iyengar

Anoxic treatment of phenolic wastewater in sequencing batch reactor

Water Res., 38 (2004), pp. 965-971

B. Wilén, P. Balmér

The effect of dissolved oxygen concentration on the structure, size and size distribution of activated sludge flocs

Water Res., 33 (2) (1999), pp. 391-400

T. Yamagishi, J. Leite, S. Ueda, F. Yamaguchi, Y. Suwa

Simultaneous removal of phenol and ammonia by an activated sludge process with cross-flow filtration

Water Res., 35 (13) (2001), pp. 3089-3096 